\title{
Clinical Characteristics and Outcomes of Patients with Ischemic and Non-Ischemic Complete Heart Block
}

Murtaza Sundhu ${ }^{1}$, Mehmet Yildiz ${ }^{1}$, Mubbasher Syed ${ }^{1}$, Bhavan Shah ${ }^{1}$, Sajjad Gul ${ }^{1}$, Omer Afzal $^{1}$, Lon Castle ${ }^{2}$

1. Internal Medicine Residency, Fairview Hospital, Cleveland Clinic, USA 2. Electrophysiology, Fairview Hospital, Cleveland Clinic, USA

$\square$ Corresponding author: Murtaza Sundhu, murtaza89ali@gmail.com

Disclosures can be found in Additional Information at the end of the article

\section{Abstract}

\section{Introduction}

Third degree or complete heart block (CHB) is a medical emergency and usually requires permanent pacemaker placement. $\mathrm{CHB}$ can be caused by cardiac ischemia or non-ischemic conditions such as infiltrative diseases or fibrosis. The purpose of this study is to identify the baseline clinical characteristics associated with ischemic versus non-ischemic causes of complete heart block and compare their outcomes.

\section{Materials and methods}

An institutional review broad approval was granted by the Cleveland Clinic Health System. In our study, 216 patients with CHB presenting to Fairview Hospital between January 2014 and June 2016 were initially identified using the International Classification of Disease (ICD) codes at discharge. Only the patients with a new diagnosis of complete heart block (CHB) were included in the study (total $\mathrm{N}=62$ ), which led to the exclusion of 154 patients. The patients were characterized into non-ischemic and ischemic groups based on cardiac marker elevation, electrocardiogram changes and/or cardiac catheterization findings. In all the patients, data including the following was collected: demographics such as age, gender, ethnicity and body mass index; pre-existing comorbidities such as hypertension, chronic kidney disease, diabetes mellitus, thyroid disease, previous coronary artery disease, history of cancer; use of nodal blocking agents, electrolyte abnormalities on admission, echocardiographic parameters such as ejection fraction (EF), right ventricular systolic pressure (RVSP), left ventricular end diastolic and systolic volumes (LVEDV and LVESV, respectively). The primary outcome was all-cause mortality and the secondary outcome was pacemaker placement. Categorical variables were analyzed using chi-square and continuous variables using ANOVA.

Received 02/26/2017 Review began 03/08/2017 Review ended 05/05/2017 Published 05/12/2017

\section{(c) Copyright 2017}

Sundhu et al. This is an open access article distributed under the terms of the Creative Commons Attribution License CC-BY 3.0., which permits unrestricted use, distribution, and reproduction in any medium, provided the original author and source are credited.

\section{Results}

Out of 62 patients $(\mathrm{N}=62), 48$ had non-ischemic and 14 had ischemic CHB. The mean age was 67 years (95\% CI, 60.55-74.73) in the ischemic group and 75 years (95\% CI, 71.52-78.80) in the non-ischemic group, $\mathrm{p}=0.04$. Patients with ischemic CHB had a lower mean EF of $49.6 \%$ (95\% CI, 42.04\%-57.23\%) compared to 57.42\% in non-ischemic CHB patients (95\% CI, 53.97\%$60.87 \%), p=0.05$. History of coronary artery disease was present in $71.4 \%(10 / 14)$ patients with ischemic CHB compared to $37.5 \%$ (18/48) patients with non-ischemic CHB, $\mathrm{p}=0.02$. There was no statistically significant difference between the two groups in terms of gender, diabetes, hypertension, thyroid dysfunction, chronic kidney disease, nodal blocking agents, electrolyte 
abnormalities or smoking status. For outcomes, 6/48 (12.5\%) of patients with non-ischemic CHB had died compared to $3 / 14$ (21.4\%) ischemic CHB ( $\mathrm{p}=0.327)$. Permanent pacemaker was implanted in $45 / 48$ patients (93.75\%) of the non-ischemic CHB compared to 6/14 (42.83\%) in the ischemic group $(\mathrm{p}<0.001)$.

\section{Conclusions}

Patients with ischemic CHB are younger, and they have a lower ejection fraction but they are less likely to get a pacemaker compared to non-ischemic CHB. Further studies with a bigger sample size are required to understand the long term mortality outcomes of patients with CHB.

Categories: Internal Medicine, Cardiology, Other

Keywords: heart block, complete heart block, cardiology, permanent pacemaker, myocardial infarction, third degree, electrophysiology, syncope

\section{Introduction}

Third degree heart block is the complete block or dissociation between the atria and the ventricles and a condition when none of the atrial impulses reach the ventricle. The causes of the third degree heart block in children could be congenital [1] or familial [2] and in adults is related to ischemia (of atrioventricular node) or could be non-ischemic including increased vagal tone, fibrosis (Lenegre's disease in patients with age <60) [3], sclerosis (Lev's disease in patients with age $>70$ ) of the conduction system [4], electrolyte abnormalities, infiltrative diseases or iatrogenic including nodal blocking medication, cardiac surgery, catheter ablations, and transcatheter aortic valve implantation.

The clinical presentation depends on the level of the block and the escape rhythm that develops as a result [5]. The escape rhythm depends on the automaticity or intrinsic rate of the tissue distil to the block [6]. The escape rhythms can be divided into narrow complex or wide complex escape rhythm based on the QRS duration (whether the QRS duration is less than or more than 120 milliseconds). Junctional or atrioventricular (AV) nodal escape rhythm develops, which is a narrow complex, when the block is within the atrioventricular node or at the level of His bundle. The escape rhythm is a wide QRS complex when the block is below the His bundle (infraHisian) [7-8].

They may be asymptomatic in very few number of cases. The presenting complains mostly include weakness, dizziness, palpitation, dyspnea, or syncope [5]. Diagnosis of the third degree heart block can be made by a 12-lead electrocardiogram and usually requires permanent pacemaker as treatment.

In this study, we try to understand the clinical characteristics pertaining to new onset CHB and carefully analyze the outcomes in ischemic and non-ischemic CHB patients as there is no comparison between these groups.

\section{Materials And Methods}

\section{Study design}

This is a retrospective observational cohort of patients admitted to the Fairview hospital from January 2014 to June 2016 with third degree heart block. The diagnosis was confirmed by an electrocardiogram by a cardiologist. The study was approved by the institutional review board of the Cleveland Clinic. Individual consent was waived because of the retrospective nature of the study. 
The patients were initially identified using the International Classification of Disease (ICD) codes applied at discharge including both ICD-9 and ICD-10 codes as there was a transition during the requested time frame. In our study, 216 patients who had a third degree heart block in their billing codes were initially identified. Patients with the age $>18$ years and a new diagnosis of the third degree heart block were included in the study. Patients with a preexisting/known history of CHB and congenital heart disease were excluded from the study. This led to the exclusion of 154 patients. Data was collected by reviewing the electronic medical records. The ischemic and non-ischemic CHB were differentiated by cardiac markers elevation, ischemic electrocardiogram changes and/or cardiac catheterization. The differentiation was made by the cardiologists.

\section{Data collection}

We collected data for the following: demographics including age, gender, ethnicity and body mass index; pre-existing comorbidities including diabetes mellitus, hypertension, previous coronary artery disease, history of cardiac surgery, acute kidney injury on admission, chronic kidney disease, thyroid disease, history of cancer; use of nodal blocking agents, electrolyte abnormalities on admission and echocardiographic findings including ejection fraction, right ventricular systolic pressure (RVSP), left ventricular end diastolic and systolic volumes. The primary outcome was all-cause mortality while the secondary outcome was permanent pacemaker placement. Outcomes were assessed by follow-up in the office or last pacemaker check. During follow-up, other parameters like percentage of right ventricular pacing, underlying rhythm, battery status of the pacemaker, sensing parameters, and follow-up echocardiogram findings including ejection fraction and RVSP were also collected.

\section{Statistical analysis}

Data analysis was performed using IBM SPSS Statistics Version 23 (IBM Corp, NY, USA). The categorical variables were compared using Fisher's exact method as there were cells with less than count of five. The continuous variables were compared using analysis of variance (ANOVA). An analysis of covariance (ANCOVA) model was created to assess the difference in initial ejection fraction and the follow-up ejection fraction to see if there was any statistically significanct difference between both groups.

\section{Results}

Among the 62 patients $(\mathrm{N}=62)$ that met the inclusion criteria, 48 had non-ischemic complete heart block and 14 had ischemic compete heart block. Out of all the patients, 69\% (43/62) were males, 37\% (23/62) had diabetes mellitus, 6.4\% (4/62) had hypothyroidism, 79\% (49/62) had hypertension, $25.8 \%(16 / 62)$ had chronic kidney disease, $45.2 \%(28 / 62)$ had a history of coronary artery disease, $25.8 \%$ (16/62) had history of cancer, $51.6 \%(32 / 62)$ were on nodal blocking agents, $11.3 \%$ (7/62) were current smokers, 56.6\% (35/62) were former smokers, and $32.6 \%$ (20/62) had never smoked (Table 1). 


\section{Cureus}

\begin{tabular}{|c|c|c|c|c|}
\hline Variables & $\begin{array}{l}\text { Total } \\
(\mathrm{N}=62)\end{array}$ & $\begin{array}{l}\text { Ischemic } \\
(\mathrm{N}=14)\end{array}$ & $\begin{array}{l}\text { Non-ischemic } \\
(\mathrm{N}=48)\end{array}$ & $\begin{array}{l}P \text { - } \\
\text { Value }\end{array}$ \\
\hline Male & $43(69.4 \%)$ & $12(85.7 \%)$ & $31(64.6 \%)$ & \multirow{2}{*}{0.12} \\
\hline Female & 19 (30.6\%) & $2(14.3 \%)$ & 17 (35.4\%) & \\
\hline Diabetes Present & $23(37.1 \%)$ & $5(35.7 \%)$ & 18 (37.5\%) & 0.58 \\
\hline Hypertension Present & 49 (79.1\%) & $11(78.6 \%)$ & 38 (79.2\%) & 0.61 \\
\hline History of thyroid Disease & $4(6.4 \%)$ & $0(0 \%)$ & $4(8.3 \%)$ & 0.34 \\
\hline $\begin{array}{l}\text { History of Coronary Artery Disease } \\
\text { Present }\end{array}$ & $28(45.2 \%)$ & $10(71.4 \%)$ & $18(37.5 \%)$ & 0.02 \\
\hline $\begin{array}{l}\text { History of Chronic Kidney Disease } \\
\text { Present }\end{array}$ & $16(25.8 \%)$ & $4(28.6 \%)$ & $12(25.0 \%)$ & 0.52 \\
\hline History of Cancer Present & $16(25.8 \%)$ & $3(21.4 \%)$ & $13(27.1 \%)$ & 0.48 \\
\hline Current Smoker & $7(11.2 \%)$ & $1(7.1 \%)$ & $6(12.5 \%)$ & \multirow{3}{*}{0.76} \\
\hline Former Smoker & 35 (56.5\%) & $9(64.3 \%)$ & 26 (54.2\%) & \\
\hline Never smoked & $20(32.3 \%)$ & $4(28.6 \%)$ & 16 (33.3\%) & \\
\hline Nodal Blocking agent prescribed & $32(51.6 \%)$ & 9 (64.3\%) & $23(47.9 \%)$ & \multirow{2}{*}{0.22} \\
\hline Nodal Blocking agents Not prescribed & $30(48.4 \%)$ & $5(35.7 \%)$ & 25 (52.1\%) & \\
\hline
\end{tabular}

\section{TABLE 1: Baseline Categorical Variables}

The mean age in the group with ischemic complete heart block was 67.64 years (95\% CI, 60.5674.73 ) and 75.60 years (95\% CI, 72.00-79.21) in non-ischemic CHB ( $p=0.04)$. The mean ejection fraction in ischemic CHB group was $49.6 \%$ (95\% CI, $42.05 \%-57.23 \%$ ) compared to $57.25 \%$ (95\% CI, $53.74 \%-60.76 \%)$ in non-ischemic CHB patients $(\mathrm{p}=0.05)$. A history of coronary artery disease was present in $71.4 \%$ (10/14) patients with ischemic CHB compared to $37.5 \%(18 / 48)$ patients with non-ischemic CHB ( $\mathrm{p}=0.02)$. The right ventricular systolic pressure (RVSP) was 33.13 (95\% CI, 21.71 - 44.54) in ischemic CHB versus 41.87 (95\% CI, 36.50-47.25) in nonischemic CHB ( $\mathrm{p}=0.17)$, which was not statistically significant (Table 2$)$.

Continuous Variables

\begin{tabular}{llllllll} 
& & & & \multicolumn{3}{c}{$\begin{array}{l}95 \% \text { Confidence Interval } \\
\text { for Mean }\end{array}$} & $\begin{array}{l}\text { P - } \\
\text { N }\end{array}$ \\
& Mean & $\begin{array}{l}\text { Std. } \\
\text { Deviation }\end{array}$ & $\begin{array}{l}\text { Std. Error } \\
\text { Lower }\end{array}$ & $\begin{array}{l}\text { Upper } \\
\text { Bound }\end{array}$ & Value \\
Ischemic & 14 & 67.64 & 12.28 & 3.28 & 60.56 & 74.73 &
\end{tabular}




\section{Cureus}

\begin{tabular}{|c|c|c|c|c|c|c|c|c|}
\hline \multirow[t]{2}{*}{ Age } & $\begin{array}{l}\text { Non- } \\
\text { Ischemic }\end{array}$ & 48 & 75.60 & 12.42 & 1.79 & 72.00 & 79.21 & \multirow[t]{2}{*}{0.04} \\
\hline & Total & 62 & 73.81 & 12.73 & 1.62 & 70.57 & 77.04 & \\
\hline \multirow{3}{*}{ Body Mass Index } & Ischemic & 12 & 29.50 & 6.72 & 1.94 & 25.23 & 33.77 & \multirow{3}{*}{0.36} \\
\hline & $\begin{array}{l}\text { Non- } \\
\text { Ischemic }\end{array}$ & 46 & 27.67 & 5.98 & 0.88 & 25.89 & 29.45 & \\
\hline & Total & 58 & 28.05 & 6.13 & 0.80 & 26.44 & 29.66 & \\
\hline \multirow{3}{*}{ Potassium } & Ischemic & 13 & 4.09 & 0.45 & 0.13 & 3.81 & 4.36 & \multirow{3}{*}{0.10} \\
\hline & $\begin{array}{l}\text { Non- } \\
\text { Ischemic }\end{array}$ & 48 & 4.37 & 0.59 & 0.08 & 4.20 & 4.54 & \\
\hline & Total & 61 & 4.31 & 0.57 & 0.07 & 4.16 & 4.46 & \\
\hline \multirow{3}{*}{ Magnesium } & Ischemic & 13 & 2.07 & 0.27 & 0.07 & 1.91 & 2.23 & \multirow{3}{*}{0.76} \\
\hline & $\begin{array}{l}\text { Non- } \\
\text { Ischemic }\end{array}$ & 46 & 2.05 & 0.26 & 0.04 & 1.97 & 2.13 & \\
\hline & Total & 59 & 2.05 & 0.26 & 0.03 & 1.99 & 2.12 & \\
\hline \multirow{3}{*}{ Ejection Fraction (EF) } & Ischemic & 11 & 49.64 & 11.30 & 3.41 & 42.05 & 57.23 & \multirow{3}{*}{0.05} \\
\hline & $\begin{array}{l}\text { Non- } \\
\text { Ischemic }\end{array}$ & 44 & 57.25 & 11.55 & 1.74 & 53.74 & 60.76 & \\
\hline & Total & 55 & 55.73 & 11.80 & 1.59 & 52.54 & 58.92 & \\
\hline \multirow{3}{*}{$\begin{array}{l}\text { Right Ventricular Systolic } \\
\text { Pressure (RVSP) }\end{array}$} & Ischemic & 8 & 33.13 & 13.65 & 4.83 & 21.71 & 44.54 & \multirow{3}{*}{0.17} \\
\hline & $\begin{array}{l}\text { Non- } \\
\text { Ischemic }\end{array}$ & 39 & 41.87 & 16.58 & 2.66 & 36.50 & 47.25 & \\
\hline & Total & 47 & 40.38 & 16.32 & 2.38 & 35.59 & 45.18 & \\
\hline \multirow{3}{*}{ EF at follow up } & Ischemic & 3 & 46.67 & 18.93 & 10.93 & -0.36 & 93.69 & \multirow{3}{*}{0.80} \\
\hline & $\begin{array}{l}\text { Non- } \\
\text { Ischemic }\end{array}$ & 17 & 44.41 & 13.84 & 3.36 & 37.30 & 51.53 & \\
\hline & Total & 20 & 44.75 & 14.13 & 3.16 & 38.14 & 51.36 & \\
\hline \multirow{3}{*}{ RVSP at follow u } & Ischemic & 3 & 39.67 & 23.25 & 13.42 & -18.08 & 97.41 & \multirow{3}{*}{0.66} \\
\hline & $\begin{array}{l}\text { Non- } \\
\text { Ischemic }\end{array}$ & 13 & 35.15 & 14.23 & 3.95 & 26.56 & 43.75 & \\
\hline & Total & 16 & 36.00 & 15.41 & 3.85 & 27.79 & 44.21 & \\
\hline
\end{tabular}

TABLE 2: Continuous Variables 


\section{Cureus}

For outcomes, 45/48 (93.75\%) patients with non-ischemic CHB had the permanent pacemaker implanted versus 6/14 (42.83\%) patients with ischemic CHB $(\mathrm{p}<0.01)$. The primary outcome of death was reported in 6/48 (12.5\%) patients with non-ischemic CHB compared to 3/14 (21.4\%) patients in ischemic CHB group ( $\mathrm{p}=0.327$ ) (Table 3 and Figure 1). The overview of the study is provided in Figure 2.

\begin{tabular}{|c|c|c|c|c|}
\hline Variable & Total $(\mathrm{N}=62)$ & Ischemic $(\mathrm{N}=14)$ & Non-ischemic $(\mathrm{N}=48)$ & $P$ Value \\
\hline \multicolumn{5}{|l|}{ Primary Outcome } \\
\hline Alive & $53(85.5 \%)$ & $11(78.6 \%)$ & 42 (87.5\%) & \multirow{2}{*}{0.327} \\
\hline Dead & 9 (15.5\%) & 3 (21.4\%) & 6 (12.5\%) & \\
\hline \multicolumn{5}{|l|}{ Secondary Outcome } \\
\hline Pacemaker Placed & $51(82.3 \%)$ & $6(42.9 \%)$ & 45 (93.8\%) & \multirow{2}{*}{$<0.01$} \\
\hline Pacemaker Not Placed & 11 (17.7\%) & $8(57.1 \%)$ & $3(6.3 \%)$ & \\
\hline
\end{tabular}

TABLE 3: Outcomes

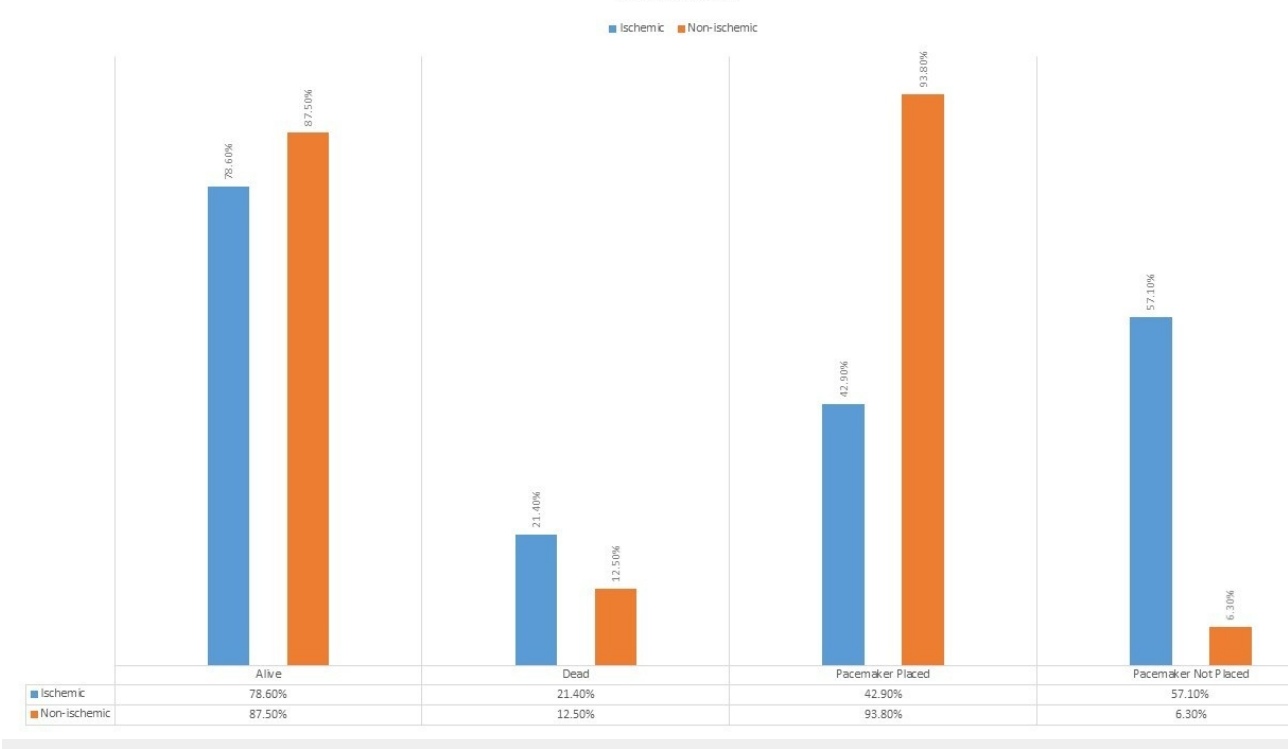

FIGURE 1: Outcomes Graph 


\section{Cureus}

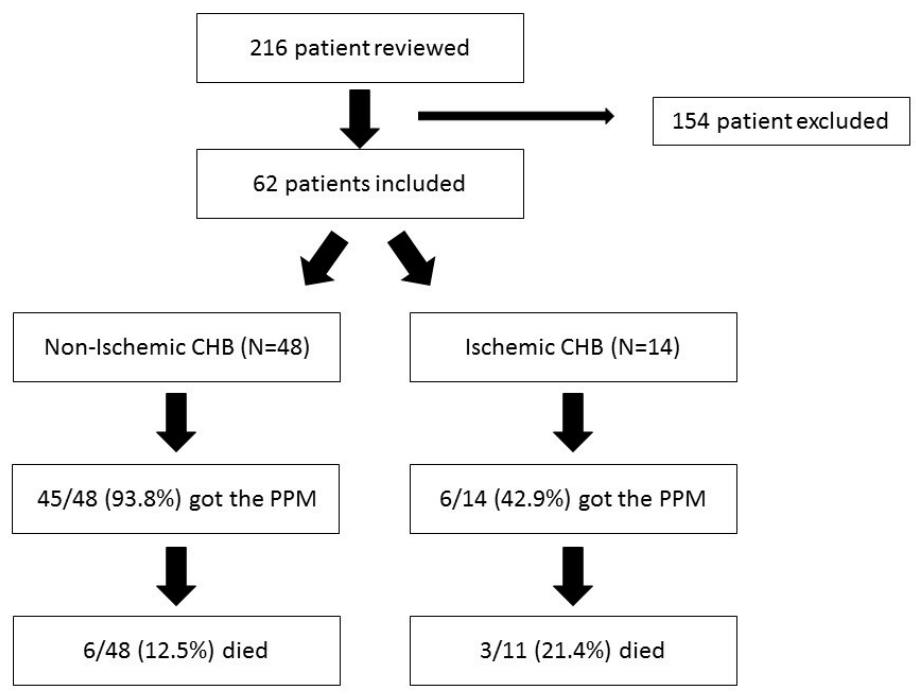

\section{FIGURE 2: Overview}

Further, an ANCOVA model was created to assess the difference between both groups in terms of the initial and follow-up ejection fraction (EF). Follow-up EF was reported for 20 patients out of whom three had ischemic CHB and 17 had non-ischemic CHB. There was no statistical difference $(\mathrm{p}=0.909)$ in the means of the $\mathrm{EF}$ difference at the time of diagnosis and follow-up visit.

\section{Discussion}

Adult-acquired (non-ischemic) complete heart block has a poor outcome without a permanent pacemaker [9]. Patients who are symptomatic do especially worse, and patients who get pacemakers do very well [9]. A permanent pacemaker is indicated when no reversible cause for complete heart block is identified [10]. Non-ischemic third degree heart block is hypothesized to be more frequent in patients with thyroid disease and diabetes [11]. In our study, there was no difference between the ischemic and non-ischemic complete heart block with regards to diabetes or thyroid disease as suggested previously [11].

The incidence of ischemic complete heart block after acute myocardial infarction has reduced [12-13]. The prognosis of acute myocardial infarction complicated by complete heart block (CHB) is poor and in-hospital death rates are significantly higher compared to patients with myocardial infarctions not associated with CHB $[12,14]$.

Ischemic and non-ischemic complete heart blocks are dealt as separate entities and we tried to study them head to head. We found no difference in terms of the pre-existing comorbidities including diabetes mellitus, hypothyroidism, hypertension, use of nodal blocking agents or chronic kidney disease. However, the patients with ischemic CHB are younger and frequently have a previous history of coronary artery disease compared to non-ischemic CHB patients. The ejection fraction is also lower in the ischemic CHB group, which is expected because of active myocardial ischemia/infarction. The right ventricular systolic pressure was higher in patients with non-ischemic $\mathrm{CHB}$, which might suggest some relationship with pulmonary hypertension, but this difference was not statistically significant.

In terms of the outcomes, the patients with ischemic $\mathrm{CHB}$ are less likely to get a permanent 
pacemaker, and the difference was statistically significant. This is because most of the CHB after myocardial ischemia resolves spontaneously. The patients with ischemic CHB died more frequently compared to the patients in the non-ischemic group, but this difference was not statistically significant. This suggests that the patients with ischemic CHB do worse than the CHB patients without ischemia.

\section{Conclusions}

Patients with ischemic complete heart block are less likely to get a pacemaker. They are younger with a lower ejection fraction at presentation and have a more frequent history of coronary artery disease. We need more studies with a bigger sample size to establish the mortality difference between them.

\section{Additional Information \\ Disclosures}

Human subjects: Consent was obtained by all participants in this study. Cleveland Clinic Institutional Review Board (IRB) issued approval 16-1464. Animal subjects: All authors have confirmed that this study did not involve animal subjects or tissue. Conflicts of interest: In compliance with the ICMJE uniform disclosure form, all authors declare the following: Payment/services info: All authors have declared that no financial support was received from any organization for the submitted work. Financial relationships: All authors have declared that they have no financial relationships at present or within the previous three years with any organizations that might have an interest in the submitted work. Other relationships: All authors have declared that there are no other relationships or activities that could appear to have influenced the submitted work.

\section{References}

1. Griffiths SP: Congenital complete heart block. Circulation. 1971, 43:615. 10.1161/01.CIR.43.5.615

2. Baruteau AE, Behaghel A, Fouchard S, et al.: Parental electrocardiographic screening identifies a high degree of inheritance for congenital and childhood nonimmune isolated atrioventricular block. Circulation. 2012, 126:1469-1477. 10.1161/CIRCULATIONAHA.111.069161

3. Lev M: Anatomic basis for atrioventricular block. Am J Med. 1964, 37:742-748.

4. Lev M: Complete atrioventricular block. Prog Cardiovasc Dis. 1964, 6:317-326.

5. Penton GB, Miller H, Levine S: Some clinical features of complete heart block . Circulation. 1956, 13:801-824. 10.1161/01.CIR.13.6.801

6. Bexton RS, Ward DE, Camm A: Electrophysiological characteristics of junctional pacemakers in congenital A-V block and following his bundle cryoablation. Clin Cardiol. 1982, 5:577-583. 10.1002/clc.4960051102

7. Puech P, Grolleau R, Guimond C: Incidence of different types of A-V block and their localization by his bundle recordings. The Conduction System of the Heart. Wellens HJJ, Lie KI, Janse MJ (ed): Springer, Netherlands; 1978. 467-484.

8. Rosen KM, Dhingra RC, Loeb HS, et al.: Heart block in adults clinical and electrophysiological observations. Arch Intern Med. 1973, 131:663-672. 10.1001/archinte.1973.00320110047006

9. Edhag O, Swahn A: Prognosis of patients with complete heart block or arrhythmic syncope . Acta Medica Scandinavica. 1976, 200:457-463. 10.1111/j.0954-6820.1976.tb08264.x

10. Epstein AE, DiMarco JP, Ellenbogen KA, et al.: ACC/AHA/HRS 2008 guidelines for devicebased therapy of cardiac rhythm abnormalities. Circulation. 2008, 117:e350-e408.

10.1161/CIRCUALTIONAHA.108.189742

11. Fairfax AJ, Leatham A: Idiopathic heart block: association with vitiligo, thyroid disease, pernicious anaemia, and diabetes mellitus. Br Med J. 1975, 4:322-324.

12. Nguyen HL, Lessard D, Spencer FA, et al.: Thirty-year trends (1975-2005) in the magnitude 


\section{Cureus}

and hospital death rates associated with complete heart block in patients with acute myocardial infarction: a population-based perspective. Am Heart J. 2008, 156:227-233. 10.1016/j.ahj.2008.03.011

13. Zoob M, Smith K: Aetiology of complete heart-block. Br Med J. 1963, 2:1149-1154.

14. Godman MJ, Lassers BW, Julian D: Complete bundle-branch block complicating acute myocardial infarct. New Engl J Med. 1970, 282:237-240. 10.1056/NEJM197001292820502 